\title{
NOTE ON THE DRAWINGS
}

Toyo Suyemoto was camp librarian at the Topaz Public Library during the final years of her internment, and the pen-and-ink drawings included in I Call to Remembrance come from the margins of a guest book for visitors to the library. The drawings, published here for the first time, are not signed, and efforts to identify the artist have so far been unsuccessful. The images provide a counterpoint narrative to that of the memoir, juxtaposing the artist's visual rendering of life in Topaz with Suyemoto's written account.

Like Toyo's prose, the spare line drawings carry an understated tone as they document common camp activities. Initial scenes show internees struggling with or searching for their baggage and watching their belongings being tossed unceremoniously into the back of a truck-a testament to the massive uprooting that has taken place. In other scenes, people are trying to settle into camp - planting trees, gathering coal for the barracks stoves, scrounging wood (probably to construct rough tables and stools for their unfurnished barracks rooms), hanging up laundry, and carrying trays of food from the mess-hall. Little children go to school; students go to the library. For pastime, people read books or papers, the Issei take their walking sticks into the desert, women knit or sew, and some internees tap at the typewriter-perhaps writing for the Topaz Times. Still, boredom characterizes life in camp, and in one scene we see a solitary man lying back amidst bottles strewn about the floor. Other drawings record the indignities of camp in a matter-of-fact manner similar to Toyo's descriptions of camp life: the crowded barracks, the assaults from ferocious dust storms, the need to lug pails and dirty clothing to the distant laundry room, as well as to don robes and geta (wooden clogs) and pack towels and toothbrushes for the bedtime trek to the communal latrine. Other depictions introduce a quiet humor in their critique of camp conditions: for example, there is a man shown eating (an apparently indigestible meal), then making tracks to the outhouse (a symbolic but not an authentic camp building); another drawing shows a couple who are sporting their newly-acquired and 
very much oversized government-issue coats. Certain other drawings even manage, in a few strokes, to illustrate the distinctions in life style between the Issei and Nisei generations that emerged and were exacerbated by the conditions of life in the camp.

The guest book is now part of the Toyo Suyemoto Special Collection in the Rare Books and Manuscripts Library of the Ohio State University Libraries. The publication of the drawings is made possible by a grant from the California Civil Liberties Public Education Program. 